\title{
Key Biodiversity Areas identification in the Upper Guinea forest biodiversity hotspot
}

\author{
O.M.L. Kouame ${ }^{1}$, N. Jengre ${ }^{2}$, M. Kobele ${ }^{3}$, D. Knox ${ }^{4}$, D.B. Ahon ${ }^{5}$, J. Gbondo ${ }^{6}$, J. Gamys ${ }^{7}$, \\ W. Egnankou ${ }^{8}$, D. Siaffa ${ }^{9}$, A. Okoni-Williams ${ }^{10} \&$ M. Saliou ${ }^{11}$
}

14744 Kenmore ave \# 202, Alexandria, VA, 22304, USA

${ }^{2}$ Hse No. 36 Abotsi Street, East Legon P. O. Box KA 9714, Airport Accra

3,11 Guinee Ecologie, 210 DI 501 Dixinn, PoB:3266 Conakry, Guinea

${ }^{4}$ The Wharton School, University of Pennsylvania, 3730 Walnut Street, Philadelphia, PA 19104, USA

${ }^{5} 22$ BP 918 Abidjan 22 Côte d'Ivoire

6150 Princeton Arms South II, East Windsor, N.J 08512, USA

${ }^{7}$ Conservation International-Liberia, Back Road, Congo Town, Monrovia, Liberia

${ }^{8}$ SOS-FORETS, 22 BP 918 Abidjan 22 Côte d'Ivoire

9 11B Becklyn Drive, Off Main Motor Road, Congo Cross, Freetown, Sierra Leone

${ }^{10}$ Fourah Bay College, University of Sierra Leone PMB Freetown, Sierra Leone

Email: ${ }^{1}$ marie_ode@hotmail.com (corresponding author), ${ }^{2}$ nbreslyn@yahoo.com, ${ }^{3}$ kobele@gmail.com, ${ }^{4}$ davidhknox@gmail.com,

${ }^{5}$ bahon2002@yahoo.fr, ${ }^{6}$ gbondojohnb@yahoo.co.uk, ${ }^{7}$ j.gamys@conservation.org, ${ }^{8}$ wadjaegnankou@hotmail.com,

${ }^{9}$ ddsiaffa@yahoo.co.uk, ${ }^{10}$ aokoni2001@yahoo.com, ${ }^{11}$ madousalioupop@yahoo.com

Date of publication (online): 06 August 2012 Date of publication (print): 06 August 2012 ISSN 0974-7907 (online) | 0974-7893 (print)

\section{Manuscript details:}

Ms \# 02717

Received 23 February 2011

Final revised received 23 May 2012

Finally accepted 05 June 2012

Citation: Kouame, O.M.L., N. Jengre, M Kobele, D. Knox, D.B. Ahon, J. Gbondo, J. Gamys, W. Egnankou, D. Siaffa, A. OkoniWilliams \& M. Saliou (2012). Key Biodiversity Areas identification in the Upper Guinea fores biodiversity hotspot. Journal of Threatened Taxa 4(8): 2745-2752.

Copyright: (C) O.M.L. Kouame, N. Jengre, M. Kobele, D. Knox, D.B. Ahon, J. Gbondo, J. Gamys, W. Egnankou, D. Siaffa, A. OkoniWilliams \& M. Saliou 2012. Creative Commons Attribution 3.0 Unported License. JoTT allows unrestricted use of this article in any medium for non-profit purposes, reproduction and distribution by providing adequate credit to the authors and the source of publication.

For Author Details, Author Contribution and Acknowledgements see end of this article.

\begin{abstract}
Priority-setting approaches and tools are commons ways to support the rapid extinction of species and their habitats and the effective allocation of resources for their conservation. The Key Biodiversity Area (KBA) approach is a method for the identification of fine-scale priority areas for conservation. This process led bottom-up has been used in the Upper Guinea Forest Ecosystem of West Africa where humaninduced changes have increased the extinction risk of several endemic and threatened species. The irreplaceability and vulnerability criteria commonly used in conservation planning have been used to identify key biodiversity areas in Ghana, Cote d'Ivoire, Liberia, Guinea and Sierra Leone. Point locality data were compiled from scientific reports, papers published in scientific journals and museum records. The delineation was conducted following a series of decision rules. In most cases existing IBA polygons and protected areas boundaries were used. For the new sites, temporary boundaries have been drawn and will be confirmed with land-use data. Preliminary KBA data were reviewed by specialists during formal workshops. One hundred and fifty four KBA have been identified in the five countries with 202 globally threatened species. Currently $63 \%$ of the KBA are protected. Two AZE sites still exist in the region. This assessment is a first step and is driven from the best available data at the time. There is a need to refine it with recent biodiversity surveys to assist decision-makers in achieving their conservation management goals.
\end{abstract}

Keywords: AZE, biodiversity, conservation planning, IUCN, Key Biodiversity Area, Upper Guinea Forest, West Africa.
The Key Biodiversity Area series documents the application of the concept and showcases the results from various parts of the world. The series is edited under the auspices of the IUCN World Commission on Protected Areas/Species Survival Commission Joint Task Force on 'Biodiversity and Protected Areas', with the editors supported by BirdLife International, Conservation International, IUCN, National Fish \& Wildlife Foundation, NatureServe, Parks Canada, and Plantlife International.

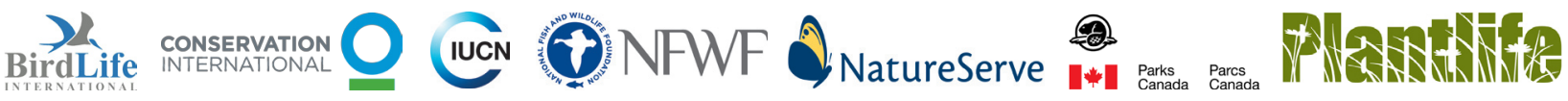




\section{INTRODUCTION}

The Upper Guinea Forest Ecosystem of West Africa extends from Guinea into eastern Sierra Leone, and eastward through Liberia, Côte d'Ivoire and Ghana into western Togo. The overall forest ecosystem of the region historically covered approximately $420,000 \mathrm{~km}^{2}$ but estimates of existing forest suggest a loss of nearly 80\% (CEPF 2000). It contains exceptionally diverse ecological communities of forest habitat, providing refuge to numerous endemic species.

The region has been the subject of several conservation assessments and priority-setting initiatives. At the global level, the Upper Guinea forest ecosystem region is considered one of the world's top priority regions for conservation because of its high endemism of flora and fauna (Bakarr et al. 2004). Another global analysis conducted on centers of plant diversity and endemism has identified 14 centers of plant endemism within the Guinean Forest Hotspot. Those coarse-scale conservation priorities do not give information on the precise locations where conservation resources should be focused. In this biologically rich and highly fragmented landscape, conservation planning and implementation stand to benefit greatly from high resolution biodiversity data (Brooks et al. 2004).

The key biodiversity areas (KBAs) approach is a method for the identification of fine-scale priority areas for conservation. KBAs are sites of global significance for biodiversity conservation that are large enough or sufficiently interconnected to support populations of the globally threatened species for which they are important (Eken et al. 2004). Conservation International and several partners in the Upper Guinea region have undertaken the identification and delineation of KBAs in five countries (Guinea, Ghana, Liberia, Côte d'Ivoire and Sierra Leone). This paper summarizes the results of applying the KBA process in the region.

\section{METHODS}

KBAs identification in Upper Guinea forest builds upon the Important Bird Areas (IBAs) identified for those five countries by the BirdLife International partnership (Fishpool \& Evans 2001). In this assessment, we have documented the presence of species of mammals, reptiles, amphibians, fish, crustaceans, butterflies and plants that trigger KBA criteria in the existing IBAs, and identify new sites triggered by species in these taxa.

KBAs are generally identified based on the confirmed presence of: (i) globally threatened species, classified as Critically Endangered (CR), Endangered (EN), or Vulnerable (VU) according to IUCN Red List (IUCN 2007); and (ii) restricted-range species, using a threshold population of $5 \%$ or more of the population of species with range-sizes of $50,000 \mathrm{~km}^{2}$ or less (Eken et al. 2004). In addition, for IBAs, criteria had been used to identify sites based on; (iii) congregations of species that concentrate at particular sites during some stage in their life cycle; and (iv) biomerestricted species assemblages (Eken et al. 2004). The first of these four criteria addresses vulnerability, while the latter three cover different components of irreplaceability (Margules \& Pressey 2000). Although a threshold of 10 pairs or 30 individuals is suggested when applying the vulnerability criteria for vertebrate species classified as VU (Langhammer et al. 2007), due to the lack of information on species abundance, we considered the confirmed occurrence of a threatened species as sufficient to trigger KBA identification.

Species occurrence data were compiled from scientific reports, papers published in scientific

Table 1. Summary data for KBA networks for each country included within the analysis.

\begin{tabular}{|l|c|c|c|c|c|c|}
\hline Country & Area $\left.\mathbf{( k m}^{2}\right)$ & \# KBAs & $\begin{array}{c}\text { Area of KBAs } \\
\left.\mathbf{( k m}^{2}\right)\end{array}$ & $\begin{array}{c}\text { \% of land surface } \\
\text { included in KBAs }\end{array}$ & $\begin{array}{c}\text { \# KBAs } \\
\text { protected } \\
\text { protected }\end{array}$ \\
\hline Côte d'Ivoire & 322,462 & 34 & 30,460 & $9 \%$ & 30 \\
\hline Ghana & 238,535 & 54 & 18,344 & $8 \%$ & 51 \\
\hline Guinea & 245,857 & 27 & 13,014 & $5 \%$ & 6 \\
\hline Liberia & 111,369 & 25 & 59,654 & $54 \%$ & $22 \%$ \\
\hline Sierra Leone & 71,740 & 15 & 11635 & $16 \%$ & $8 \%$ \\
\hline
\end{tabular}




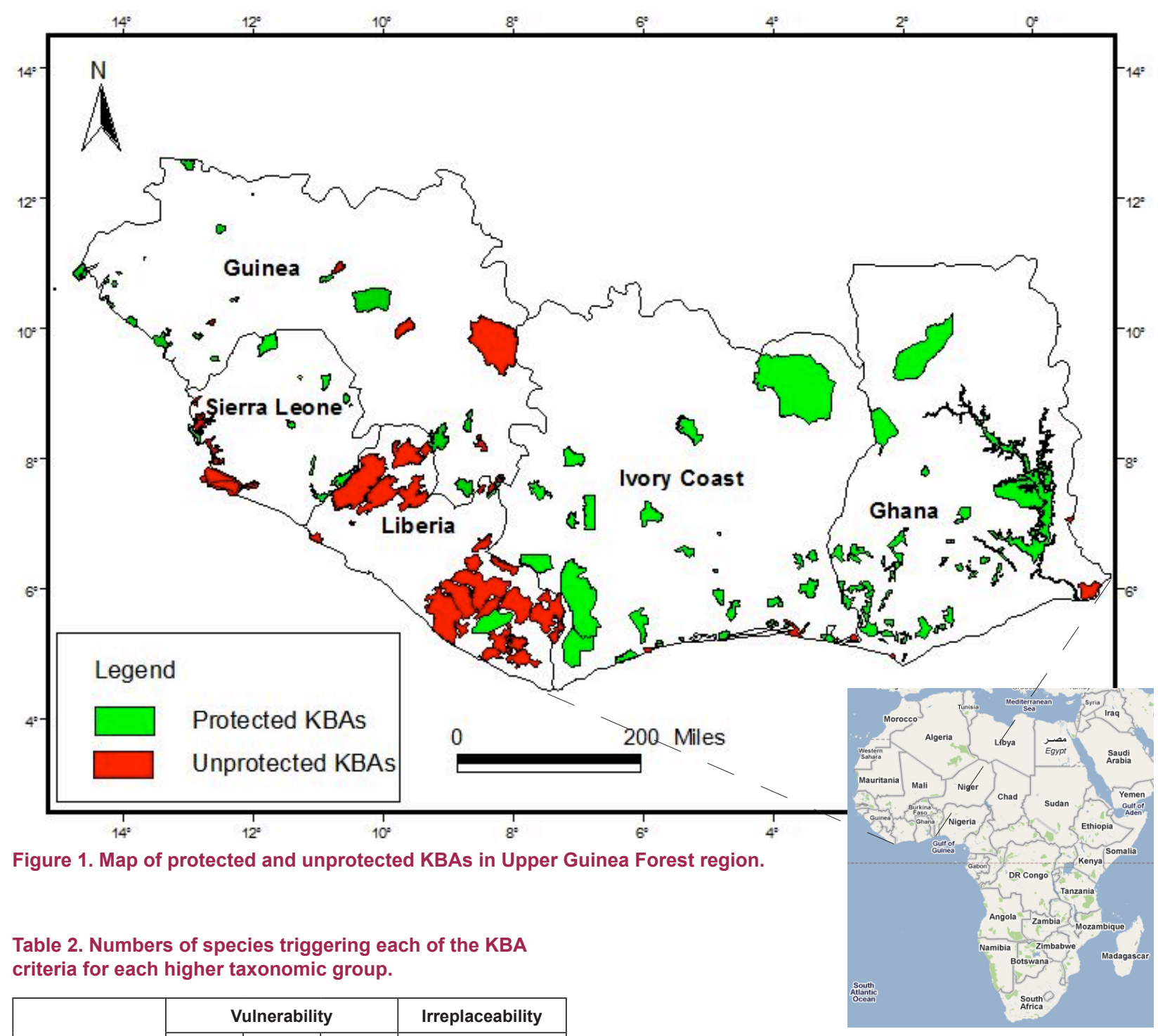

\begin{tabular}{|l|c|c|c|c|}
\hline \multirow{2}{*}{ Higher taxon } & \multicolumn{3}{|c|}{ Vulnerability } & Irreplaceability \\
\cline { 2 - 5 } & CR & EN & VU & Restricted-range \\
\hline Mammals & 2 & 9 & 190 & 27 \\
\hline Birds & 1 & 2 & 9 & 15 \\
\hline Reptiles & 2 & 3 & 3 & 4 \\
\hline Amphibians & 5 & 9 & 6 & 26 \\
\hline Actinopterygii & 0 & 1 & 1 & 5 \\
\hline Chondrichthyes & 4 & 3 & 3 & 0 \\
\hline Crustaceans & 0 & 1 & 0 & 0 \\
\hline Butterflies & 0 & 0 & 0 & 88 \\
\hline Plants & 4 & 24 & 91 & 498 \\
\hline
\end{tabular}

2008). Most of the plant data came from the Oxford University Herbaria online database (OUH 2011). Butterfly data came from Larsen (2006). For the reptiles, occurrence data were extracted mainly from Okoni-Williams et al. (2005). Fish data were compiled from Dankwa et al. (1999), Ofori-Danson et al. (2003) and Ofori-Danson \& Kumi (2006). Additional sources are listed in Appendix I.

Spatial data used to delineate the KBAs boundaries included available point localities and distribution information for species, IBA polygons, and protected journals and museum records. Mammal data were obtained from primary surveys and Rapid Assessment Program (RAP) reports. The majority of amphibian data were provided by Rödel et al. (2005) and by the IUCN Global Amphibian Assessment (Stuart et al. areas (PA) boundaries. In some cases, existing IBA or PA boundaries were modified as needed to incorporate nearby habitat for target species. For the new sites, temporary boundaries have been drawn and will be confirmed with land-use data. The KBAs were 
Table 3. Numbers of KBAs triggered by each of the criteria for each higher taxonomic group.

\begin{tabular}{|l|c|c|c|c|}
\hline \multirow{2}{*}{ Higher taxon } & \multicolumn{3}{|c|}{ Vulnerability } & Irreplaceability \\
\cline { 2 - 5 } & CR & EN & VU & Restricted-range \\
\hline Mammals & 3 & 90 & 96 & 32 \\
\hline Birds & 1 & 18 & 73 & 77 \\
\hline Reptiles & 6 & 6 & 9 & 3 \\
\hline Amphibians & 5 & 20 & 26 & 18 \\
\hline Actinopterygii & 0 & 1 & 1 & 1 \\
\hline Chondrichthyes & 4 & 5 & 4 & 0 \\
\hline Crustaceans & 0 & 1 & 0 & 0 \\
\hline Butterflies & 0 & 0 & 0 & 4 \\
\hline Plants & 9 & 35 & 88 & 89 \\
\hline
\end{tabular}

reviewed by specialists during formal workshops during October 2008 in Ghana, Sierra Leone and Ghana.

\section{RESULTS}

We identified 154 KBAs representing between 5\% and $54 \%$ of the land surface of each country (Table 1, Fig. 1 ), and $13 \%$ of the region overall. In total, 1,032 species trigger the KBA criteria with 202 (132 VU, $52 \mathrm{EN}, 18$ CR) globally threatened species and 663 restricted-range species (Table 2 and Table 3). For IBAs, three sites were also identified for 27 species based on the congregations/ aggregations criteria, and 33 sites using the biomerestricted assemblage criterion, for 217 species.

A total of 97 KBAs are currently protected (63\%), while 57 are not covered by the existing protected areas system (Table 1). Protected area coverage is particularly low in Liberia, with only two of the country's 25 KBAs protected (8\%).

With regards to the number of species that trigger site identification, only nine sites $(6 \%)$ were identified for a
Table 4. Number of trigger species per KBA, and the number of KBAs per trigger species.

\begin{tabular}{|l|c|c|}
\hline $\boldsymbol{n}$ & $\begin{array}{c}\text { \# KBAs holding } \boldsymbol{n} \\
\text { trigger species }\end{array}$ & $\begin{array}{c}\text { \# trigger species } \\
\text { occurring in } \boldsymbol{n} \text { KBAs }\end{array}$ \\
\hline 1 & 9 & 273 \\
\hline 2 & 9 & 154 \\
\hline 3 & 4 & 106 \\
\hline 4 & 6 & 91 \\
\hline 5 & 8 & 53 \\
\hline 6 & 7 & 45 \\
\hline 7 & 1 & 32 \\
\hline 8 & 1 & 24 \\
\hline 9 & 3 & 20 \\
\hline 10 & 3 & 19 \\
\hline 11 & 3 & 13 \\
\hline 12 & & 4 \\
\hline 13 & 2 & 14 \\
\hline 14 & 2 & 12 \\
\hline 15 & 1 & 13 \\
\hline 16 & & 5 \\
\hline 17 & & 5 \\
\hline 18 & & 3 \\
\hline 19 & & 4 \\
\hline 20 & & 39 \\
\hline$>20$ & & \\
\hline & & 3 \\
\hline
\end{tabular}

single species, while $92(60 \%)$ were triggered by more than 20 species (Table 4). Within the region, 273 species occur in one KBA only, while one species occurs in no fewer than 68 KBAs (Table 4).

Two KBAs that hold the only record of at least one highly threatened species, and which hold six such species in total (Table 5), were identified as triggering the criteria for Alliance for Zero Extinction sites (Ricketts et al. 2005; AZE 2010).

Table 5. Data for highly threatened species occurring at only one KBA globally

\begin{tabular}{|l|l|l|l|l|}
\hline KBA & Country & Species & Higher taxon & IUCN Red List category \\
\hline \multirow{4}{*}{ Mont Nimba } & \multirow{3}{*}{$\begin{array}{l}\text { Côte d'Ivoire/ } \\
\text { Guinea/ } \\
\text { Liberia }\end{array}$} & Arthroleptis crusculum & Amphibian & EN \\
\cline { 3 - 5 } & & Hyperolius nimbae & Amphibian & EN \\
\cline { 3 - 5 } & & Hipposideros lamottei & Mammal & CR \\
\cline { 3 - 5 } & \multirow{2}{*}{ Taï } & Aimbaphrynoides liberiensis & Amphibian & CR \\
\hline & \multirow{2}{*}{ Côte d'Ivoire } & Amietophrynus taiensis & Amphibian & CR \\
\cline { 3 - 5 } & & Hyperolius nienokouensis & Amphibian & EN \\
\hline
\end{tabular}




\section{DISCUSSION}

The KBAs identified in the five countries of the Upper Guinea forest appear to provide a valuable update more than a decade after the Elmina Conservation Priority-Setting Workshop held in 1999 in Ghana (Conservation International 2001). They give a better idea of the current remaining priorities for species and site-scale conservation in the region.

The absence of recent biodiversity surveys and the shortfall in collaboration between conservationists and scientists in the universities and research centers require that the analysis draws from historical records, available in open access online databases. As a result, we have identified several "provisional" KBAs, sites that are suspected to be important, but for which only historical data have been collected (we excluded these candidate sites from the analysis above). We also need to delineate new KBAs to ensure that all threatened species are represented in the network of important sites because some species still fall outside the delineated sites.

Another limitation is that marine and freshwater species are poorly documented. In this initial application of the KBA approach, the criteria for biomes restricted and congregatory species have been assessed only for birds, for which Birdlife International has conducted and tested their applicability in IBA identification.

Changes in knowledge have driven some changes to AZE site identification over the last five years. Bobiri Forest Reserve, in Ghana, is no longer considered an AZE site because the frog Hyperolius bobirensis (EN), previously considered endemic, has now been recorded in Ankasa and Atewa forest reserves in Ghana (Rödel et al. 2005; McCullough et al. 2007). Similarly Adiopodoumé, in Côte d'Ivoire, is now no longer considered an AZE site because Crocidura wimmeri is now tagged as a 'Possibly Extinct' Critically Endangered species (IUCN 2010).

The majority of KBAs are legally protected as national parks, forest reserves and classified forest. It is important to emphasize that most of them are not managed effectively and they are under severe threats such as forest loss and fragmentation due to agricultural expansion, exploitative logging, rapid population growth, and bushmeat hunting. Mining is having a growing impact particularly in the Nimba
Mountains KBAs. According to Bongers et al. (2004), all Upper Guinea sites except for National Parks are considered to have shortage of effective protection. Chatelain et al. (2004) show that in the large majority of classified forest in Côte d'Ivoire, $40-50 \%$ of these forests have been replaced by planted crops and trees. By contrast, in Ghana, some KBAs are labeled as "Globally Significant Biodiversity Areas" to focus effort to protect the remaining priority sites. In Liberia, Cape Mount, Lofa-Gola-Mano Complex and Wonegizi mountains are in the process of being protected. The governments of Liberia and Sierra Leone have also started the formal processes of designating the Gola Rainforest as a shared National Park and Protected Area.

Considerable conservation opportunities still exist in the region due to the presence of internationally recognised sites such as Ramsar sites, UNESCO World Heritage sites and Biosphere Reserve sites. The Critical Ecosystem Partnership Fund investment in the Upper Guinea Forest, initiated in 2000, has been crucial in mobilizing local and international conservation organizations. This investment has also catalyzed further resources from bilateral donors and the private sector (CEPF 2006). For example, Conservation International and local partners are now implementing conservation activities in the Greater Nimba Highlands in Guinea with support from the U.S. Agency for International Development and Rio Tinto.

The current challenge is to secure sustainable financing for the known priority areas of the region. The growing market for climate mitigation and other payment for environmental services mechanisms appear to be opportunities to leverage conservation for human benefit. Several countries in the hotspot - Ghana and Liberia in particular - are emerging as leaders in the development of green economic pilots and policies for Reducing Emissions from Deforestation and Degradation (REDD). Conservation International, through CEPF consolidation investments, is playing a leading role in promoting and supporting learning between emerging REDD and payments for ecosystem services pilots in each of the countries which are demonstrating innovative approaches to biodiversity conservation and human well-being in the known priority areas. 


\section{REFERENCES}

AZE (2010). 2010 AZE Data available at http://www. zeroextinction.org. Accessed on 22 December 2010.

Bakarr, M., J.F. Oates, J. Fahr, M.P.F. Parren, M.-O. Rödel \& R. Demey (2004). Guinean forests of West Africa, pp. 123-130. In: Mittermeier, R.A., P.R. Gil, M. Hoffman, J. Pilgrim, T. Brooks, C.G. Mittermeier, J. Lamoreux \& G.A.B. Da Fonseca (eds.). Hotspots Revisited: Earth's Biologically Richest and Most Endangered Terrestrial Ecoregions. CEMEX \& Conservation International, Mexico City \& Washington, D.C., 392pp.

Bongers, F., L. Poorter, V. Beligné, W.D. Hawthorne F.N. Kouame, M.P.E. Parren \& D. Traoré (2004). Implications for conservation and management, pp. 87-98. In: Bongers, L.F., F.N.G. Kouamé \& W.D. Hawthorne (eds.). Biodiversity of West African Forest: An Ecological Atlas of Woody Plants Species. CABI Publishing, Wallingford, 521pp.

Brooks, T., G.A.B. Fonseca \& A.S.L. Rodrigues (2004). Species, data, and conservation planning. Conservation Biology 18: 1682-1688.

Chatelain, C., H. Dao, L. Gautier \& R. Spichiger (2004). Forest cover changes in Cote d'Ivoire and Upper Guinea, pp 15-32. In: Poorter, L., F. Bongers, F.N.G. Kouamé \& W.D. Hawthorne (eds.). Biodiversity of West African Forest: An Ecological Atlas of Woody Plant Species. CABI Publishing, Wallingford, $521 \mathrm{pp}$.

Conservation International (2001). From the Forest to the Sea: Biodiversity Connections from Guinea to Togo. Conservation Priority-Setting Workshop, December 1999. Washington D.C.

CEPF (2006). Assessing Five Years of CEPF Investment: Guinean Forests of West Africa Biodiversity Hotspot Upper Guinean Forest Ecosystem; A Special Report, 71pp.

CEPF (2000). Ecosystem Profile: Upper Guinean Forest, Guinean Forests of West Africa.

Dankwa, H.R., E.K.Abban \& G.G. Teugels (1999). Freshwater Fishes of Ghana: Identification, distribution, ecological and economic status. Annales Science Zoologiques 283: 53pp

Eken, G., L. Bennun, T.M. Brooks, W. Darwall, L.D.C. Fishpool, M. Foster, D. Knox, P. Langhammer, P. Matiku, E. Radford, P. Salaman, W. Sechrest, M.L. Smith, S. Spector \& A. Tordoff (2004). Key biodiversity areas as site conservation targets. BioScience 54: 1110-1118.

Fishpool, L.D.C. \& M.I. Evans (2001). Important Bird Areas in Africa and Associated Islands: Priority Sites for Conservation. Cambridge, UK: BirdLife International.

IUCN (2007). IUCN Red List of Threatened Species. Version 2007. Accessed on 19 December 2007.

IUCN (2010). IUCN Red List of Threatened Species. Version 2010ab. Accessed on 28 November 2010.

Langhammer, P.F., M.I. Bakarr, L.A. Bennun, T.M. Brooks, R.P. Clay, W. Darwall, N. De Silva, G.J. Edgar, G. Eken, L.D.C. Fishpool, G.A.B. Fonseca, M.N. Foster da, D.H. Knox, P. Matiku, E.A. Radford, A.S.L. Rodrigues, P. Salaman, W. Sechrest \& A.W. Tordoff (2007).
Identification and Gap Analysis of Key Biodiversity Areas: Targets for Comprehensive Protected Area Systems. Gland, Switzerland: IUCN, 116pp.

Larsen, T.B. (2006). The Ghana Butterfly Fauna and its Contribution to the Objectives of the Protected Areas System. WDSP Report no. 63. Wildlife Division (Forestry Commision) and IUCN (World Conservation Union) 207pp.

Margules, C.R. \& R.L. Pressey (2000). Systematic conservation planning. Nature 405: 243-253

McCullough, J., L.E. Alonso, P. Naskrecki, H.E. Wright \& Y. Osei-Owusu (eds.). (2007). A Rapid Biological Assessment of the Atewa Range Forest Reserve, Eastern Ghana. RAP Bulletin of Biological Assessment Vol. 47. Conservation International, Arlington, VA.

Ofori-Danson, P.K. \& G.N. Kumi (2006). Food and feeding habits of Sarotherodon melanotheron, Rüppell, 1852 (Pisces: Cichlidae) in Sakumo Lagoon, Ghana. West African Journal of Applied Ecology 10: 21-32.

Ofori-Danson, P.K., K.V. Waerebeek \& S. Debrah (2003). A survey for the conservation of dolphins in Ghanaian coastal waters. Journal of the Ghana Science Association 5(2): $45-54$.

Okoni-Williams, A., H.S. Thompson, A.P. Koroma \& P. Wood (2005). Important Bird Areas in Sierra Leone: priorities for biodiversity conservation. Conservation Society of Sierra Leone and Forestry Division, GOSL.

OUH (2011) Oxford University Herbaria. Available online at: http://dps.plants.ox.ac.uk/bol/oxford.

Ricketts, T.H., E. Dinerstein, T. Boucher, T.M. Brooks, S.H.M. Butchart, M. Hoffmann, J.F. Lamoreux, J. Morrison, M. Parr, J.D. Pilgrim, A.S.L. Rodrigues, W. Sechrest, G.E. Wallace, K. Berlin, J. Bielby, N.D. Burgess, D.R. Church, N. Cox, D. Knox, C. Loucks, G.W. Luck, L.L. Master, R. Moore, R. Naidoo, R. Ridgely, G.E. Schatz, G. Shire, H. Strand, W. Wettengel \& E. Wikramanayake (2005). Pinpointing and preventing imminent extinctions. Proceedings of the National Academy of Sciences of the U.S.A. 102: 18497-18501.

Rödel, M.-O, M. Gil, A.C. Agyei, A.D. Leaché, R.E. Diaz, M.K. Fujita \& R. Ernst (2005). The amphibians of the forested parts of south-western Ghana. Salamandra 41(3): $107-127$

Stuart, S., M. Hoffmann, J. Chanson, N. Cox, R. Berridge, P. Ramani \& B. Young (eds.) (2008). Threatened Amphibians of the World. Lynx Edicions, IUCN, and Conservation International, Barcelona, Spain; Gland, Switzerland; and Arlington, Virginia, USA, xv+758pp.

Appendix I. Additional data sources

Adou, Y.C.Y., E.C. Blom, K.T.S. Dengueadhé, R.S.A.R. Van Rompaey, E.K. N' Guessan, G. Wittebolle \& F. Bongers (2005). Diversité floristique et végétation dans le Parc National de Taï, Côte d'Ivoire.- Tropenbos-Côte d'Ivoire, série 5, 92pp.

Ahon, D.B. \& B. Kadjo (2008). Inventaire préliminaire de la 
faune avifaunique et mammalienne de la Forêt Classée de Besso. Rapport d'étude, Abidjan, 32pp.

Ahon, D.B. (2008). Inventaire préliminaire de la faune aviaire de la Forêt des marais Tanoé. Rapport d'étude, Abidjan, 16 p.

Ahon, D.B., Assé, A.F. \& K.P. Kouadio (2005). Liste préliminaire des oiseaux de la Forêt Classée de Dassioko. Rapport d'étude, Abidjan, 10pp.

Alonso, L.E., F. Lauginie \& G. Rondeau (eds.) (2005). Une évaluation biologique de deux forêts classées du sud-ouest de la Côte d'Ivoire. Bulletin RAP d'Evaluation Rapide Vol. 34, Conservation International. Washington, D.C., 168pp.

Bangoura, F. (1977). Etude systématique de la flore de Kaback, 99pp.

Barnett, A.A. \& M.L. Prangley (1997). Mammalogy in the Republic of Guinea: an overview of research from 1946 to 1996, a preliminary check-list and a summary of research recommendations for the future. Mammal Review 27(3): 115-164.

BirdLife International (2004). Threatened Birds of the World 2004. CD-ROM. BirdLife International, Cambridge, UK.

Cole, N.H.A. (1993). Floristic association in the Gola rain forests: a proposed biosphere reserve. Journal of Pure and Applied Science 2: 35-50.

Dankwa, H.R., E.K. Abban \& G.G. Teugels (1999). Freshwater Fishes of Ghana: Identification, Distribution, Ecological and Economic Status. Annales Science Zoologiques, Vol. 283, 53pp.

Dantily, D. (2002). Plan d'aménagement : Forêt classée de Balayan Souroumba. Winrock International, 91pp.

Dantily, D. (2002). Plan d'aménagement forêt classée de Sincery-Oursa. Winrock International 2002, 89pp.

Demey, R. \& L.D.C. Fishpool (1991). Additions and annotations to the avifauna of Côte d'Ivoire. Malimbus 12: 61-86.

Demey, R. (2003). Rapport de mission: formation en ornithologie de terrain. BirdLife International.

Egnankou, W.M., Kadjo, B. \& D.B. Ahon (2005). Inventaire de la faune et de la flore de Dahlia fleur. Rapport, Abidjan, Côte d'Ivoire, 38pp.

Fishpool, L.D.C \& M.I. Evans (eds.) (2001). Important Bird Areas in Africa and Associated Islands: Priority Sites for Conservation. Newbury: Pisces Publications \& Cambridge, UK: BirdLife International.

Gartshore, M.E., P.D. Taylor \& I.S. Francis (1995). Forest Birds in Côte d'Ivoire. A survey of Taï National Park and other forests and forestry plantations, 1989-1991. Birdlife International, Cambridge, UK, 55pp.

Hoke, P., R. Demey \& A. Peal (eds.) (2007). A rapid biological assessment of North Lorma, Gola and Grebo National Forests, Liberia. RAP Bulletin of Biological Assessment 44. Conservation International, Arlington, VA, USA.

Kéita, K. (2000). Projet Biodiversité Kankan II «Promotion des organismes de mise en œuvre en vue de la sauvegarde de la biodiversité de la réserve de Kankan», V2, 79pp.

Klop, E., Lindsell, J. \& A. Siaka (2008). Biodiversity of Gola
Forest, Sierra Leone. Internal report to RSPB, CSSL and the Government of Sierra Leone.

Koné, I., Béné, K., N'guessan, A.K., Bitty, A.E., Koffi, D.A., Akpatou, K.B. \& S. Gonedele (2008). Conservation des primates en Afrique de l'Ouest: la Forêt des Marais Tanoé (Sud-est de la Côte d'Ivoire) identifiée comme étant un site à Haute Valeur de Conservation en péril.- Abidjan; argumentaire, $17 \mathrm{pp}$.

Kormos, R., C. Boesch, M.I. Bakarr \& T. Butynski (eds.) (2003). West African Chimpanzees. Status Survey and Conservation Action Plan. IUCN/SSC Primate Specialist Group. IUCN, Gland, Switzerland and Cambridge, UK, 219pp.

Lachenaud, O. (2006). Les oiseaux du Parc National du Banco et de la Forêt Classée de l'Anguédédou. Malimbus 28: 107-132.

Lamotte, M. (eds.) (1998). Le Mont Nimba. Réserve Biosphère et Site du Patrimoine Mondial (Guinée et Côte d'Ivoire). UNESCO, Paris, 153pp.

Larsen, T.B. (2005). Butterflies of West Africa. 2 volumes. Apollo Books, 596pp+125pls.

Lauginie, F. (2007). Conservation de la nature et aires protégées en Côte d'Ivoire. NEI/Hachette et Afrique Nature, Abidjan, Côte d'Ivoire, 668pp.

Mabinty, D. (2003). Impacts socio économiques du classement de la forêt de Kakiyiré dans la CRD de Kanfarandé.

McCullough, J. (2004). A Rapid Biological Assessment of Forêt Classée du Pic de Fon, Simandou Range, Southeastern Republic of Guinea. RAP Bulletin of Biological Assessment, Vol. 35. Conservation International, Washington, D.C., 248pp.

McCullough, J., J. Decher \& D.G. Kpelle (eds.) (2005). $A$ biological assessment of the terrestrial ecosystems of the Draw River, Boi-Tano, Tano Nimiri and Krokosua Hills forest reserves, southwestern Ghana. RAP Bulletin of Biological Assessment, Vol. 36. Conservation International, Washington, D.C.

McCullough, J., J.P. Hoke \& P. Naskrecki (eds.) (2006). Rapid Biological Assessment of the Ajenjua Bepo and Mamang River Forest Reserves, Eastern Region, Ghana, Vol 50. Rap Bulletin of Biological Assessment.

Rödel, M.-O. \& R. Ernst (2000). Bufo taiensis n.sp., eine neue Kröte aus dem Taï-Nationalpark, Elfenbeinküste. Herpetofauna 22(125): 9-16.

Rödel, M.-O. \& R. Ernst (2003). The amphibians of Marahoué and Mont Péko National Parks, Ivory Coast. Herpetozoa 16: 23-39.

Rödel, M.-O. \& W.R. Branch (2002). Herpetological survey of the Haute Dodo and Cavally forests, western Ivory Coast, Part I: Amphibians. Salamandra 38: 245-268.

SOS-Forêts, (2004). Inventaire de l'avifaune du Parc National des Iles Ehotilés. Rapport non publié; Abidjan, Côte d'Ivoire, $15 \mathrm{pp}$.

Thiollay, J.M. (1985). The birds of Ivory Coast: status and distribution. Malimbus 7: 1-59.

Wright, H.E., J. McCullough \& M.S.A. Diallo (eds.) (2006). 
Rapid biological assessment of Boke prefecture, Northwestern Guinea. RAP Bulletin of Biological Assessment, Conservation International, Washington, D.C., 192pp.

Wright, H.E., J. McCullough, L.E. Alonso \& M.S.A. Diallo (eds.) (2003). Rapid Biological Assessment of Three Classified Forests in Southeastern Guinea. RAP Bulletin of Biological Assessment, Vol. 40. Conservation International, Washington, D.C., 248pp.
Acknowledgements: The KBAs process in West Africa was made possible with the support of a number of environmental NGOs, government institutions and agencies as well as individual experts. In Ghana, they include the Ghana Environmental Protection Agency, Ghana Ministry of Environment Science and Technology, Ghana Forestry Commission, Forestry Research Institute of Ghana, Ghana Wildlife Division, and the Resource Management Support Centre of the Ghana Forestry Commission. Others are the Ghana Wildlife Society, BirdLife InternationalGhana, Friends of the Earth - Ghana, West African Primate Conservation Action - Ghana Centre for African Wetlands - Ghana, Butterfly Conservation of Ghana, University of Ghana University for Development Studies - Ghana and University of Cape Coast - Ghana. Beyond Ghana, key institutions include the Conservation Society of Sierra Leone, SOS-FORETS of Côte d'Ivoire, Guinee-Ecologie, University of Conakry, University of Cocody - Abidjan, Centre National de Floristique -Abidjan, Société de Développement des Forêts - Côte d'Ivoire, Office Ivoirien des Parcs et Réserves - Côte d'Ivoire, Direction des Parcs Nationaux - Côte d'Ivoire, Centre Suisse de Recherches Scientifiques - Côte d'Ivoire, Wild Chimpanzee Foundation - Côte d'Ivoire, Centre d'Etude et de Recherche en Environnement (Guinea), Ministry of Environment of Guinea, Centre National de Recherche Halieutique of Boussoura - Guinea, Ministry of Agriculture of Sierra Leone, Forestry and Food Security, Ministry of Fisheries and Marine Resources of Sierra Leone, Bumbuna Hydroelectric Project, Institute of Marine Biology and Oceanography, University of Sierra Leone (Department of Biological Sciences, Fourah Bay College) and Department of Biological Sciences- Njala, Forestry Development Authority of Liberia, Society for Conservation of Nature of Liberia, Fauna and Flora International-Liberia.

Author Details: Ode MARIE-Louise KouAme is currently working as an independent consultant. She was previously the West Africa Coordinato with Conservation International to coordinate the identification of KBA in the upper guinea forest. She worked on several CEPF and Bird Life Internationa projects on the inventory of IBA in Cote d'Ivoire. She finalized her $\mathrm{PhD}$ on wetland Ecology and it's expected to be defended in September.

NICHOLAS JENGRE holds an MPhil degree in environmental science, with strong background in forestry, natural resources management and biodiversity conservation. $\mathrm{He}$ is currently the Regional Research and Evaluation Coordinator for Rainforest Alliance West African Office in Ghana. Nicholas has deep experience in carbon stocks sampling in both terrestrial and aquatic landscapes.
MAmAdy Kobele specializes in environmental management and climate change. He was a Chevening Scholar at the World Conservation Monitoring Centre. In Guinea he served as a team leader at the environmental NGO Guinee Ecologie where he is currently the Executive Director.

DAVID KNOX is currently a management consultant with the Boston Consulting Group. Prior to BCG, he spent 7 years with Conservation International in South Africa. David holds a MBA from The Wharton School, a MSc in Conservation Biology from the University of Cape Town and a BS from the University of North Carolina.

Dr. DibiÉ Bernard Ahon is Ornithologist and Animal Biological Lecturer at the University of Daloa, Côte d'Ivoire_West Africa. He also collaborate with the NGO SOS Forêts (BirdLife International's affiliate of Côte d'Ivoire) as the IBA's Officer .

JoHN GBONDo has recently relocated in the USA $\mathrm{He}$ served as Botanist at the Department of Biological Sciences FBC- USL (Fourah Bay College, University of Sierra Leone). He was also an Executive Secretary at Conservation Society of Sierra Leone (CSSL) and collaborated on IBA and KBA projects. John hold a B.Sc Hons in Botany. Joel Gamys is Conservation Manager for Conservation International Liberia. In addition to his role to contribute to local partners' capacity strengthening in conservation project planning and implementation, he is involved in biodiversity field research activities in Liberia. He is also leading land use planning activities in Northern Nimba Conservation Area.

Dr. Egnankou Wadja Mathieu is a botanist, wetland expert and lecturer at the University of Cocody, Cote d'Ivoire. He is also the founder and president of the NGO SOS-FORETS. He is a Goldman Environmental prize winner.

DANIEL SIAFFA was the former executive director of the Conservation Society of Sierra Leone (CSSL) ARNOLD OKONI-WILLIAMS is currently a conservation ecologist and a lecturer of the Biological Sciences Department of the University of Sierra Leone. For several years, he worked as a biodiversity conservation officer for the Conservation Society of Sierra Leone (CSSL). He is currently undertaking a $\mathrm{PhD}$ study on vegetation, carbon and nutrient cycling in the bush fallow systems and the potential benefits to farming communities and the environment in Sierra Leone.

Mamadou Salou is the President of the NGO Guinee-Ecologie. He coordinated a number of rapid assessment program with Conservation International as well as conservation activities on IBA in Guinea with BirdLife International.

Author Contribuion: All the authors have contributed to both the study and the current paper.

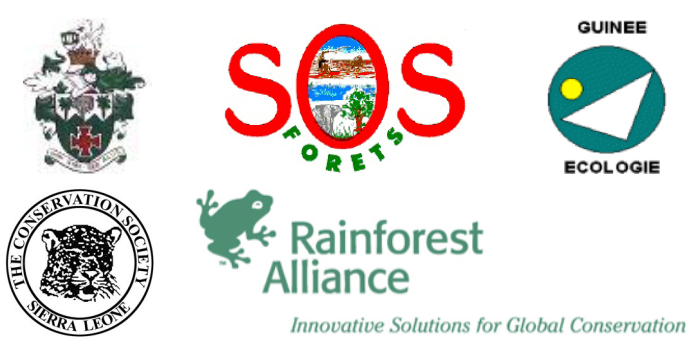

